\title{
Pengaruh Lingkungan Pemasaran Terhadap Pendapatan Usaha \\ Sentra Industri Pengolahan Salak Agrina Parsalakan
}

\section{Oleh: 1) Masnilam Hasibuan, 2) Vince Napitupulu Fakultas Ekonomi,Universitas Graha Nusantara, Padang Sidempuan \\ Masnilam75@gmail.com}

\begin{abstract}
This study aims to determine how much influence the marketing environment has on the business income of the salak agrina parsalakan processing industry center. This research uses a quantitative design, quantitative research is research that involves measuring the level of a certain feature. Quantitative research includes every type of research based on calculations, percentages, averages, and other calculations. In other words, this research uses numerical or quantity calculations.

The marketing environment consists of actors and forces outside of marketing that influence the ability of marketing management to build and maintain successful relationships with target customers. Income arising from the sale of merchandise, products or services within a certain period in the framework of activities for or which are the main objectives of the company which are directly related to the main business (operations) of the company concerned. The purpose of this study was to determine the effect of the marketing environment on income at the industrial processing center of Salak Agrina Parsalakan. The sample in this study were 20 customers of the Salak Agrina Parsalakan Processing Industry Center. The data collection techniques used were interviews, questionnaires and documentation studies. Testing the results of the analysis partially obtained a positive and significant value as indicated by the t test where the $t$ value is 2.973, while the value of the t table is 1.734 so the $t$ value is greater than the table or 2.973>1.734 using a significant level of 5\% and $d f$ (degree of freedom) $=n-2$, namely 20-2 = 18. Based on the results of the analysis, it can be seen that the marketing environment will affect income, which shows a positive and significant value, the coefficient of determination is 32.9\%. while the rest is influenced by factors not examined by the authors of 67.1\%.973> 1,734 using a significant level of 5\% and $d f$ $($ degree of freedom $)=n-2$, namely 20-2 $=18$. Based on the results of the analysis, it can be seen that the marketing environment will affect income shows a positive and significant value, the
\end{abstract}


coefficient of determination is $32,9 \%$. while the rest is influenced by factors not examined by the authors of 67.1\%. 973> 1,734 using a significant level of 5\% and df (degree of freedom) $=n-2$, namely 20-2 = 18. Based on the results of the analysis, it can be seen that the marketing environment will affect income shows a positive and significant value, the coefficient of determination is 32 , 9\%. while the rest is influenced by factors not examined by the authors of $67.1 \%$.

Keywords: Marketing Environment, Income.

\section{PENDAHULUAN}

Pemasaran merupakan bagian dari manajemen perusahaan dan juga salah satu faktor yang sangat penting, karna pemasaran akan mempengaruhi secara langsung terhadap kelancaran maupun keberhasilan perusahaan dalam mencapai tujuannya. Penting bagi perusahaan untuk mengetahui strategi pemasaran yang tepat dan sesuai untuk produk yang akan dijual di pasaran. Dengan strategi pemasaran tepat dan sesuai maka produk akan mudah diterimacalon konsumen sehingga calon konsumen membeli produk yang dijual. Selain strategi pemasaran perusahaan perlu mengetahui posisi produk yang dijual. Posisi disinimenujukkan perbandingan mengenai pasar-pasar dan pertumbuhan pasar dari para pesaingan produk yang sejenis dari perusahaan lain.

Keberhasilan perusahaan dalam memasarkan produk-produk sangat tergantung pada kiat-kiat dan strategi pemasaran yang dilakukan karena dengan penerapan strategi pemasaran yang tepat, perusahaan dapat mencapai dan memelihara serta mengembangkan permitaan konsumen secara menyakinkan dan berkesinambungan.

Lingkungan menjadi unsur penting dalam sebuah proses pemasaran, karena lingkungan juga menjadi faktor berpengaruh untuk memaksimalkan suatu aktivitas. Keadaan suatu lingkungan juga menjadi tolak ukur dan pembanding dengan suatu keadaan lain untuk disesuikan dengan keadaan yang diharapkan, sehingga potensi yang ada dapat diserap dan dimaksimalkan untuk mencapai tujuan tertentu. Lingkungan adalah keadaan sekitar yang memiliki karakteristik, keunikan, perbedaan, potensi, ancaman dan fungsi yang bermacam-macam dimana keadaan ini memberikan timbal balik sesuai dengan apa yang terjadi, baik secara langsung dan tidak langsung.

Untuk objek penelitian ini adalah Lingkungan Pemasaran Terhadap Pendapatan Usaha Sentra Industri Pengolahan Salak 
Agrina Parsalakan. Di kota Padangsidimpuan tepatnya di parsalakan terkenal dengan banyak buah salak.Melihat potensi yang dimiliki harus ditindak lanjutkan dengan bagaimana strategi pemasaran yang tepat untuk mendukung agar kedepanya usaha salak ini bisa maju dan berkembang. Salah satu nya adalah strategi pemasaran yang sudah dilakukan Usaha Sentra Industri Pengolahan Salak Agrina Parsalakan dilakukan selama ini adalah secara langsung berinteraksi dengan kosumen, menawarkan produk melalui iklan. Dengan melihat lingkungan pemasaran yang secara baik proses pemasaran produknya dapat berjalan dengan baik sehingga usaha Agrina menghasilkan pendapatan/profit.

Pendapatan adalah pendapatan yang timbul dari penjualan barang dagangan, produk atau jasa dalam periode tertentu dalam rangka kegiatan atau yang menjadi tujuan utama perusahaan yang berhubungan langsung dengan usaha (operasi) pokok perusahaan yang bersangkutan, Pendapatan juga merupakan faktor yang sangat penting dalam operasi suatu perusahaan, karena pendapatan akan mempengaruhi tingkat laba yang diharapkan akan menjamin kelangsungan hidup perusahaan.

Dalam hal ini pendapatan bertujuan untuk meningkatkan penghasilan (income) adalah kenaikan manfaat ekonomi selama satu periode akuntansi dalam bentuk pemasukan atau penambahan aset atau penurunan kewajiban yang mengakibatkan kenaikan ekuitas yang tidak berasal dari kontribusi penanam modal.

Pembatasan masalah perlu dilakukan mengingat keterbatasan-keterbatasan yang dimiliki oleh penulis / peneliti, baik batas waktu, tenaga dan biaya, referensi buku yang menjadi rujukan dan juga pengetahuan yang dimiliki oleh penulis.Pembatasan masalah bertujuan untuk menghindari pembahasan yang terlalu luas sehingga pembahasan terhadap permasalahan akan lebih mantap dan terfokus. Penelitian ini akan membatasi pembahasan dan analisis dalam hal lingkungan pemasaran sebagai penunjang yang dapat meningkatkan pendapatan perusahaan dan lingkuangan yang disesuaikan latar belakang.

Berdasarkan latar belakang diatas, maka permasalahan yang ada dapat dirumuskan sebagai berikut:
1. Apakah
Lingkungan
Pemasaran berpengaruh positif terhadap Pendapatan?
2. Apakah Lingkungan Pemasaran dapat mempengaruhi pendapatan Usaha Setra Industri Pengolahan Salak Agrina Parsalakan?




\section{BAHAN DAN METODE}

\section{Pemasaran}

Kegiatan pemasaran untuk menjalankan bisnis, guna memnuhi kebutuhan pasar dengan barang atau jasa, menetapkan harga, mendisribusikan, serta mempromosikannya.

Pengertian pemasaran dalam suatu perusahaan mencakup ruang lingkup yang luas. Kegiatan ini merupakan salah satu aktivitas penting dari seluruh usaha yang dilakukan prusahaan terutama bagi perusahaan - perushaan yang berorientasi pada profit dalam upaya memenuhi kebutuhan dan keinginan konsumen. Kebutuhan dan keinginan konsumen haruslah mendapat perhatian yang serius dari manajemen perusahaan, karena dewasa ini banyak produk sejenis yang ditawarkan oleh banyak perusahaan, sehinggga tersedia banyak alternatif bagi konsumen dalam memenuhi kebutuhan dan keingiannya. Kondisi seperti ini menuntut perusahaan untuk mengidentifikasi dengan baik apa yang benat-benar menjadi kebutuhan dan keinginan konsumen sebelum mereka memproduksi produk dalam melakukan aktivitas pemasaran lainnya.

Menurut Philip Kotler dan Keller (2009 : 05) menyatakan bahwa "Pemasaran merupakan fungsi organisasi dan serangkaian proses untuk menciptakan, mengkomunikasikan dan memberikan nilai kepada pelanggan untuk mengelola hubungan pelanggandengan cara yang menguntungkan organisasi dan pihak-pihak yang berkepentingan terhadap organisasi”.

\section{a. Lingkungan Mikro Pemasaran}

Lingkungan Mikro Pemasaran merupakan pelaku yang dekat dengan perusahaan dan memengaruhi kemampuan perusahaan untuk melayani pelanggannya. Lingkungan mikro pemasaran terdiri dari: perusahaan, pemasok, perantara pemasaran, pasar pelanggan, pesaing, danmasyarakat.

Masyarakat, masyarakat lokal, masyarakat umum, masyarakat internal.

\section{b. Lingkungan Makro Pemasaran}

Lingkungan Makro pemasaran merupakan kekuatan sosial yang lebih besar yang mepengaruhi lingkungan mikro pemasaran. Lingkungan makro pemasaran terdiri dari: Lingkungan demografis, ekonomi, alam, teknologi, politik, dan budaya. lingkungan demografi

Demografi adalah studi kependudukan manusia menyangkut ukuran, kepadatan, lokasi, usia, jenis kelamin, ras, lapangan kerja, dan data statistic lain. Lingkungan demografi menjadi minat utama perusahaan karena lingkungan demografis menyangkut 
masyarakat, dan masyarakat membentuk pasar.

\section{Pendapatan Usaha}

Pendapatan merupakan tujuan utama dari pendirian suatu perusahaan. Sebagai suatu organisasi yang berorientasi profit maka pendapatan mempunyai peranan yang sangat besar. Pendapatan merupakan faktor penting dalam operasi suatu perusahaan, karena pendapatan akan mempengaruhi tingkat laba yang diharapkan akan menjamin kelangsungan hidup perusahaan.

$$
\text { Menurut Kartikahdi (2012:186) }
$$
penghasilan (income) adalah kenaikan manfaat ekonomi selama satu periode akuntansi dalam bentuk pemasukan atau penambahan aset atau penurunan kewajiban yang mengakibatkan kenaikan ekuitas yang tidak berasal dari kontribusi penanam modal

Kemudian Lam dan Lau (2014:317) mengemukakan pengertian pendapatan sebagai berikut: Pendapatan (revenue) adalah arus masuk bruto dari manfaat ekonomis selama periode berjalan yang muncul dalam rangkaian kegiatan biasa dari sebuah entitas ketika arus masuk dihasilkan 9 dalam penambahan modal, selain yang berkaitan dengan kontribusi pemegang ekuitas. Ikatan Akuntan Indonesia (2015) mendefinisikan: Pendapatan adalah penghasilan yang timbul dari pelaksanaan aktivitas entitas yang normal dan dikenal dengan sebutan yang berbeda, seperti penjualan, penghasilan jasa, bunga, dividen, royalti, dan sewa.

Pendapatan merupakan nilai maksimum yang dapat dikonsumsi oleh seseorang dalam suatu periode dengan mengharapkan keadaan yang sama pada akhir periode seperti keadaan semula.Pengertian tersebut menitikberatkan pada total kuantitatif pengeluaran terhadap konsumsi selama satu periode.

Konsep pendapatan dapat ditelusuri dari 2 sudut pandang, yaitu:

1. Pandangan yang menekankan pada pertumbuhan atau peningkatan jumlah aktiva yang timbul sebagai hasil dari kegiatan operasional perusahaan. Pendekatan yang memusatkan perhatian kepada arus masuk atau inflow.

2. Pandangan yang menekankan kepada penciptaan barang dan jasa oleh perusahaan serta penyerahan barang dan jasa.

\section{Kerangka pemikiran}

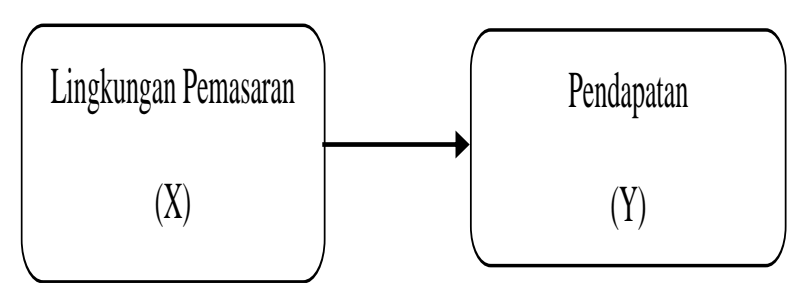




\section{Hipotesis}

Hipotesis menurut (Sugiyono: 2012) adalah merupakan jawaban sementara atas permasalahan yang diteliti. Dikatakan sementara karena jawaban yang diberikan baru didasarkan pada fakta-fakta empiris yang diperoleh melalui pengumpulan data. Jadi hipotesis juga dapat dinyatakan sebagai jawaban teoritis terhadap rumusan masalah peneliti, belum jawaban yang empirik. Berdasarkan rumusan masalah peneliti, maka hipotesis yang diajukan adalah :

1. "Diduga bahwa Lingkungan Pemasaran Berpengaruh positif dan signifikanpada PendapatanUsaha Sentra Industri Pengolahan SalakAgrina Parsalakan”.

2. "Diduga bahwa Lingkungan Pemasaran dapat Mempengaruhi secara positif dan signifikan pada Pendapatan Usaha Sentra Industri Pengolahan Salak Agrina Parsalakan".

\section{METODE PENELITIAN}

Metode penelitian berfungsi untuk membantu pelaksanaan penelitian berjalan dengan baik, yang dipergunakan dalam penelitian ini adalah metode kuantitatif, yaitu suatu proses yang menggunakan data berupa angka sebagai alat untuk menemukan keterangan mengenai apa yang akan diteliti, yang dipergunakan dalam penelitian ini adalah metode kuantitatif dengan teknik pengumpulan data menggunakan kuesioner ( angket ). Dimana kuesioner merupakan teknik pengumpulan data yang dilakukan dengan cara memberi seperangkat pertanyaan atau pernyataan tertulis kepada responden untuk dijawab.

\section{Populasi dan Sampel}

Populasi adalah wilayah generalisasi yang terdiri atas objek / subjek yang mempunyai kualitas dan karakteristik tertentu yang ditetapkan oleh peneliti untuk dipelajari dan kemudian ditarik kesimpulannya. Populasi dalam penelitian ini diperkirakan 200 orang dalam kurun waktu 1 tahun, yaitu pelanggan dari Usaha Sentra Industri Pengolahan Salak Agrina parsalakan.

Menurut Arikunto ( 2006 : 85 ), apabila subjek penelitian kurang dari 100, lebih baik diambil semua sehingga penelitiannya merupakan penelitian populasi. Jika jumlah subjeknya besar dapat diambil antara 10 $15 \%$ atau 20 - 55\% atau lebih, tergantung sedikit banyaknya waktu, tenaga, dana yang dimiliki oleh peneliti, sempit luasnya wilayah pengamatan dari setiap subjek, dan juga besar kecilnya resiko yang ditanggung oleh peneliti. Sesuai dengan pernyatan pernyataan di atas penentuan sampel menggunakan pernyataan dari Arikunto sebagai berikut: 


$$
\begin{aligned}
& \mathrm{n}=\text { Jumlah Populasi } \times 10 \% \\
& \mathrm{n}=200 \times 10 \% \\
& \mathrm{n}=20
\end{aligned}
$$

Jadi, responden yang diambil dalam penelitian ini adalah 20 pelanggan yang berbelanja di Usaha Sentra Industri Pengolahan Salak Agrina Parsalakan. Dan pengambilan sampel dengan menggunakan teknik Insidental Sampling yang diperoleh dari kurun waktu 1 bulan dengan kriteria yang telah dijelaskan oleh penulis.

\section{Instrumen Penelitian}

Instrumen dalam penelitian ini terdapat dua variabel Lingkungan Pemasaran (X) variabel bebas, dan Pendapatan (Y) variabel terikat.

1. Jenis Data

a. Data Primer

Data Primer adalah data yang berisikan fakta - fakta atau keterangan yang secara langsung diperoleh melalui penelitian lapangan dari obyek yang diteliti, data ini peneliti peroleh melalui wawancara kepada pelanggan, dengan menggunakan daftar pertanyaan yang telah dipersiapkan sebelumnya.

b. Data Skunder

Data skunder adalah data sejumlah fakta atau keterangan yang diperoleh peneliti secara langsung maupun tidak langsung melalui bahan, keterangan atau peraturan perundang-undangan, arsip, lembaga atau instansi terkait dan sebagainya yang berkaitan dengan masalah yang penulis teliti.

2. Sumber Data

a. Sumber Data Primer

Sumber data primer yaitu sumber data yang secara langsung memberi keterangan, yang dalam hal ini konsumen yang berbelanja di Usaha Sentra Industri Pengolahan Salak Agrina Persalakan.

b. Sumber Data Skunder

Sumber data skunder yaitu sumber data yang secara tidak langsung memberi keterangan yang bersifat mendukung data primer.

Data sangat berpengaruh dalam hasil penelitian. Karena pemilihan metode pengumpulan data yang tepat akan diperoleh data yang relevan dan akurat. Metode pengumpulan data yang digunakan dalam penelitian ini adalah :

1. Wawancara

Wawancara adalah salah satu teknik pengumpulan data yang akurat untuk keperluan proses pemecahan masalah tertentu yang sesuai dengan data. 
Pencarian data dengan teknik ini dapat dan dilakukan dengan cara tanya jawab secara lisan dan telah dipublikasikan baik jurnal ilmiah, penelitian terdahulu, maupun literatur yang berhubungan dengan penelitian ini.

2. Kuesioner

Kuesioner adalah salah satu cara pengumpulan data dengan memberikan atau menyebarkan daftar pertanyaan kepada responden.

3. Studi dokumentasi

Studi Dokumentasi dilakukan dengan mengumpulkan dan mempelajari dokumen yang diperoleh dari lokasi penelitian.

\section{Metode Analisis Data}

\section{Uji Validitas dan Reliabilitas}

\section{Uji Validitas}

Uji validitas dilakukan untuk mengukur apakah data yang telah didapat setelah penelitian merupakan data yang valid dengan alat ukur yang digunakan (kuesioner), validitas menunjukkan sejauh mana suatu alat pengukur itu mampu mengukur apa yang ingin diukur (Prof. Dr.Sugiyono, 2013 : 270). Dalam penelitian ini sampel uji validitas diambil sebanyak 30 pelanggan, yaitu masyarakat yang berbelanja di Usaha Sentra Industri Pengolahan Salak Agrina menggunakan program SPSS 23.00 for windows dengan kriteria sebagai berikut :

1. Jika $\mathrm{r}$ hitung $>\mathrm{r}$ tabel, maka pernyataan tersebut dinyatakan valid.

2. Jika $\mathrm{r}$ hitung $<\mathrm{r}$ tabel, maka pernyataan tersebut dinyatakan tidak valid.

\section{Uji Reliabilitas}

Reliabilitas merupakan tingkat kendala suatu instrumen penelitian. Instrumen yang reliabel adalah instrumen yang apabila digunakan berulang kali untuk mengukur objek yang sama akan menghasilkan data yang sama.

( Prof. Dr. Sugiyono, 2013 : 270 ). Uji reliabilitas akan dapat menunjukkan konsistensi dari jawaban-jawaban responden yang terdapat pada kuesioner.

Uji ini dilakukan setelah uji validitas dan yang diuji merupakan pernyataan yang sudah valid. Dalam penelitian ini dilakukan uji validitas dan reliabilitas dengan menggunakan bantuan program SPSS versi 23.00. Butir pernyataan yang sudah dinyatakan valid dalam uji validitas akan ditentukan reliabilitasnya.

Instrumen yang valid dan reliabel merupakan syarat mutlak untuk mendapatkan hasil penelitian yang valid dan reliabel. Uji validitas dan reliabilitas dilakukan untuk menguji apakah kuesioner layak digunakan sebagai instrumen penelitian atau tidak. Valid 
artinya data yang diperoleh melalui kuesioner dapat menjawab tujuan penelitian. Reliabel artinya data yang diperoleh melalui kuesioner hasilnya konsisten bila digunakan untuk peneliti lain.

Uji reliabilitas ini dilakukan untuk melihat apakah alat ukur yang digunakan menunjukkan konsistensi dalam mengukur gejala yang sama.

a) Jika $\mathrm{r}_{\text {hitung }}>\mathrm{r}$ tabel maka pertanyaannya valid.

b) Jika $\mathrm{r}$ hitung $<\mathrm{r}$ tabel maka pertanyaannya tidak reliabel.

\section{Teknik Analisis Data}

Dalam menganalisa besarnya pengaruh variabel bebas terhadap variabel terikat digunakan model ekonometrika dengan meregresikan variabel yang ada dengan menggunakan metode regeresi linear sederhana. Variabel tersebut dibuat dahulu dalam bentuk funugsi sebagai berikut :

$$
\mathbf{Y}=\mathbf{a}+\mathbf{b X} \mathbf{e}
$$

Keterangan

\section{Y : Lingkungan Pemasaran}

X : Pendapatan

a : Konstanta

b : KoefisienRegresi

e : Eror

\section{Uji t-Statistik ( Uji Parsial )}

Uji t-Statistik merupakan suata pengujian secara parsial yang bertujuan untuk mengetahui apakah masing - masing koefisien regresi signifikan atau tidak terhadap variabel dependent dengan menganggap variabel independent lainnnya konstan. Dalam hal ini digunakan hipotesis sebagai berikut :

Uji - $\mathrm{t}$ menentukan seberapa besar pengaruh variabel bebas secara parsial terhadap variabel terikat.

$\mathrm{H}_{0}: \beta \mathrm{i}=0$ artinya tidak terdapat pengaruh yang positif dari variabel bebas $(\mathrm{X})$ terhadap variabel terikat $(\mathrm{Y})$.

$$
\mathrm{H}_{\mathrm{a}}: \beta \mathrm{i} \neq 0 \text { artinya secara parsial }
$$
terdapat pengaruh yang positif dari variabel bebas (X) terhadap variabel terikat (Y). Pengujian menggunakan Uji - $\mathrm{t}$ dengan tingkat pengujian pada $\alpha=5 \%$ derajat kebebasan ( degree of freedom $)$ atau $\mathrm{df}=(\mathrm{n}-\mathrm{k})$ Kriteria pengambilan keputusan: H0 diterima jika t hitung $>\mathrm{t}$ tabel pada $\alpha=5 \% \quad \mathrm{H}_{\mathrm{a}}$ diterima jika $\mathrm{t}$ hitung $<\mathrm{t}_{\text {tabel }}$ pada $\alpha=5 \%$.

\section{Koefisien Determinasi}

Koefisien determinasi (R-Square) dilakukan untuk melihat seberapa besar kemampuan variabel independen secara bersama dapat memberikan penjelasan terhadap variabel dependen dimana nilai $r^{2}$ 
berkisar antara 0 sampai $1\left(0 \leq \mathrm{R}^{2} \leq 1\right)$.

Dapat dilihat seperti dibawah ini :

$$
\mathrm{KD}=\mathbf{r}^{2} \times 100 \%
$$

KD : Koefisien Determinasi

$r^{2} \quad$ : Nilai Koefisien Korelasi

\section{HASIL DAN PEMBAHASAN}

\section{Hasil Uji Validitas dan Reliabilitas}

\section{Uji Validitas}

Uji validitas dilakukan untuk mengukur apakah data yang telah didapat setelah penelitian merupakan data yang valid dengan alat ukur yang digunakan (kuesioner). Dalam penelitian ini sampel uji validitas diambil sebanyak 20 responden, yaitu pelanggan Agro Rimba Nusantara (Agrina) dengan menggunakan program SPSS 23.00 for windows dengan kriteria sebagai berikut:

1. Jika $\mathrm{r}_{\text {hitung }}>\mathrm{r}_{\text {tabel, }}$ maka pernyataan tersebut dinyatakan valid.

2. Jika $\mathrm{r}_{\text {hitung }}<\mathrm{r}_{\text {tabel, }}$, maka pernyataan tersebut dinyatakan tidak valid.

3. Nilai $r$ hitung dapat dilihat di tabel Item-

Tabel 4.4

Uji Validitas

\begin{tabular}{|c|c|c|c|c|c|}
\hline No & Variabel & Pernyataan & $\begin{array}{c}\mathbf{r} \\
\text { hitung }\end{array}$ & $\begin{array}{c}r \\
\text { tabel }\end{array}$ & Validitas \\
\hline 1 & \multirow{5}{*}{$\begin{array}{l}\text { Lingkungan } \\
\text { Pemasaran } \\
\text { (X) }\end{array}$} & P1 & 0,698 & 0,378 & Valid \\
\hline 2 & & P2 & 0,651 & 0,378 & Valid \\
\hline 3 & & P3 & 0,854 & 0,378 & Valid \\
\hline 4 & & $\mathrm{P} 4$ & 0,802 & 0,378 & Valid \\
\hline 5 & & P5 & 0,753 & 0,378 & Valid \\
\hline 6 & \multirow{5}{*}{$\begin{array}{l}\text { Pendapatan } \\
\text { (Y) }\end{array}$} & P1 & 0,779 & 0,378 & Valid \\
\hline 7 & & $\mathrm{P} 2$ & 0,923 & 0,378 & Valid \\
\hline 8 & & P3 & 0,849 & 0,378 & Valid \\
\hline 9 & & $\mathrm{P} 4$ & 0,891 & 0,378 & Valid \\
\hline 10 & & P5 & 0,952 & 0,378 & Valid \\
\hline
\end{tabular}

Sumber : Pengolahan Data SPSS 23.00 Tahun 2020
Total Statistic pada kolom corrected item total correlation di lampiran.

Penyebaran kuesioner khusus dalam uji validitas dan reabilitas diberikan kepada 20 responden dengan kriteria yang telah dijelaskan sebelumnya. Nilai $r$ tabel dengan ketentuan $\mathrm{df}=\mathrm{N}-2$, maka angka yang diperoleh df $=20-2=18$ maka 0.378 (lampiran), dilakukan dengan pengujian didapat sebagai berikut :

Dari hasil pengujian validitas pada tabel di atas dapat diketahui semua item pernyatan pada kuesioner mempunyai nilai r-hitung lebih besar dari nilai r-tabel dengan nilai r semuanya positif sehingga dapat disimpulkan bahwa semua item pertanyaan dapat dinyatakan valid

\section{Uji Reliabilitas}

Suatu kuesioner dikatakan reliabel atau handal jika jawaban dari responden terhadap pernyataan adalah konsisten atau stabil dari waktu ke waktu. Suatu konstruk atau variabel dikatakan reliabel jika memberikan nilai cronbach alpha> 0,60. Hasil pengujian reliabilitas kuisioner variabel penelitian dapat dilihat sebagai berikut:

Pada tingkat signifikansi 5\% diketahui bahwa koefisien alpha (Cronbach's Alpha) untuk variabel Lingkungan Pemasaran (X) adalah 0,900, dan untuk variabel Pendapatan (Y) adalah 
Tabel 4.5

Uji Reliabilitas

\begin{tabular}{|c|c|c|c|c|}
\hline No & Variabel & $\begin{array}{c}\text { Cronbach } \\
\text { Alpha }\end{array}$ & $\begin{array}{c}\text { Batas } \\
\text { Minimum }\end{array}$ & Keterangan \\
\hline 1 & $\mathrm{X}$ & 0,900 & 0,60 & Reliabel \\
\hline 2 & $\mathrm{Y}$ & 0,956 & 0,60 & Reliabel \\
\hline
\end{tabular}

Sumber : Pengolahan Data SPSS 23.00 Tahun 2020

\section{0,956Reability Statistic dilampiran.}

Sehingga dapat dinyatakan bahwa kuesioner tersebut telah reliabel dan dapat disebarkan kepada responden untuk dijadikan sebagai instrumen penelitian.

\section{Analisis Regresi Linear Sederhana}

Analisis regresi linear sederhana dilakukan dengan bantuan SPSS23.00 dengan tujuan untuk mengetahui seberapa besar pengaruh variabel bebas yang terdiri dari, Lingkugan Pemasaran terhadap variable terikat yaitu PendapatanPadaUsaha Sentra Industri Pengolahan Salak Agrina Parsalakan.
Model persamaan yang digunakan dalam penelitian ini adalah sebagai berikut :

$$
\begin{gathered}
Y=a+b X \\
Y=8,501+0,590
\end{gathered}
$$

Berdasarkan persamaan tersebut dapat digambarkan sebagai berikut : Konstanta sebesar 8,501, artinya jika Lingkungan Pemasaran (X) nilainya adalah 0 , maka jumlah Kepuasan Pelanggan (Y) nilainya positif yaitu sebesar 0,590.Koefisien $X=8,501$ (dapat dilihat pada table 4.6 Coefficients $^{a}$ ). Ini berarti bahwa variable Lingkungan Pemasaran (X) berpengaruh positif terhadap Pendapatan (Y) Pada Usaha Sentra Industri Pengolahan Salak Agrina Parsalakan. Dengan kata lain jika Lingkungan Pemasaran ditingkatkan sebesar satu-satuan, maka Kepuasan Pelanggan akan bertambah sebesar $\quad 0,590 . \quad$ Uji

\section{SignifikanParsial (Uji-t)}

Tabel 4.6

Hasil UjiRegresi Linear Sederhana

\begin{tabular}{|c|c|c|c|c|c|c|}
\hline \multirow{2}{*}{\multicolumn{2}{|c|}{ Model }} & \multicolumn{2}{|c|}{$\begin{array}{c}\text { Unstandardized } \\
\text { Coefficients }\end{array}$} & \multirow{2}{*}{$\begin{array}{c}\text { Standardized } \\
\text { Coefficients } \\
\text { Beta }\end{array}$} & \multirow[b]{2}{*}{$\mathrm{T}$} & \multirow[b]{2}{*}{ Sig. } \\
\hline & & B & Std. Error & & & \\
\hline \multirow[t]{2}{*}{1} & (Constant) & 8.501 & 3.905 & & 2.177 & .043 \\
\hline & $\begin{array}{l}\text { Lingkungan } \\
\text { Pemasaran }(\mathrm{X})\end{array}$ & .590 & .199 & .574 & 2.973 & .008 \\
\hline
\end{tabular}
Coefficients $^{\mathrm{a}}$

a. Dependent Variable: Pendapatan (Y)

Sumber : Pengolahan Data SPSS 23.00 Tahun 2020
Tabel 4.7

\section{Hasil Uji Parsial (Uji t)}

\begin{tabular}{|c|c|c|c|c|c|c|}
\hline \multirow{2}{*}{\multicolumn{2}{|c|}{ Model }} & \multicolumn{2}{|c|}{$\begin{array}{c}\text { Unstandardized } \\
\text { Coefficients }\end{array}$} & \multirow{2}{*}{\begin{tabular}{|c|}
$\begin{array}{c}\text { Standardized } \\
\text { Coefficients }\end{array}$ \\
Beta \\
\end{tabular}} & \multirow[b]{2}{*}{$\mathrm{t}$} & \multirow[b]{2}{*}{ Sig. } \\
\hline & & B & Std. Error & & & \\
\hline 1 & (Constant) & 8.501 & 3.905 & & 2.177 & .043 \\
\hline & $\begin{array}{l}\text { Lingkungan } \\
\text { Pemasaran }(X)\end{array}$ & .590 & .199 & .574 & 2.973 & .008 \\
\hline
\end{tabular}

\section{Coefficients $^{\mathrm{a}}$}

a. Dependent Variable: Pendapatan (Y)

Sumber : Pengolahan Data SPSS 23.00 Tahun 2020 
Uji t menunjukkan seberapa besar pengaruh variabel bebas secara individual terhadap variabel terikat. Kriteria pengujiannya adalah :

$\mathrm{H}_{0}: \mathrm{b} 1=0$, Artinya secara parsial terdapat pengaruh yang positif dan signifikan dari variabel

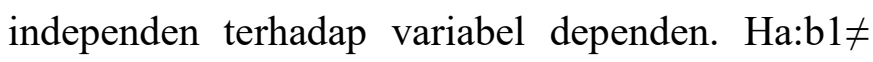
0,Artinya secara parsial tidak terdapat pengaruh yang positif dan signifikan dari variabel independen terhadap variabel dependen. Kriteria pengambilan keputusan adalah $: \mathrm{H}_{0}$ diterima jika $t_{\text {hitung }}>$ t tabel $_{\text {pada }} \alpha=5 \%$

Ha ditolak jika $t_{\text {hitung }}<\mathrm{t}_{\text {tabel }}$ pada $\alpha=5 \%$

$\mathrm{t}$ hitung(dapat dilihat pada tabel Coeffficiens ${ }^{a}$ )

$\mathrm{t}$ tabel(dapat dilihat pada tabel $\mathrm{t}$ di lampiran )

Berdasarkan Tabel coefficients ${ }^{a}$ dapat dilihat bahwa : Nilai thitung variabel Lingkungan Pemasaran ( X ) adalah2,973, dan nilai $\mathrm{t}_{\text {tabel }} 1,734$ maka $\mathrm{t}_{\text {hitung }}>\mathrm{t}$ tabel $(2,973>1,734)$ sehingga dapat disimpulkan bahwa variabel Lingkungan Pemasaran (X) berpengaruh positif dan signifikan secara parsial terhadap Pendapatan (Y) pada Usaha Sentra Industri Pengolanhan Salak Agrina Parsalakan.JadiH 0 diterima sebab $t_{\text {hitung }}>t_{\text {tabel }}(2,973>1,734)$.

\section{Pengujian Koefisien Determinasi $\left(\mathbf{r}^{2}\right)$}

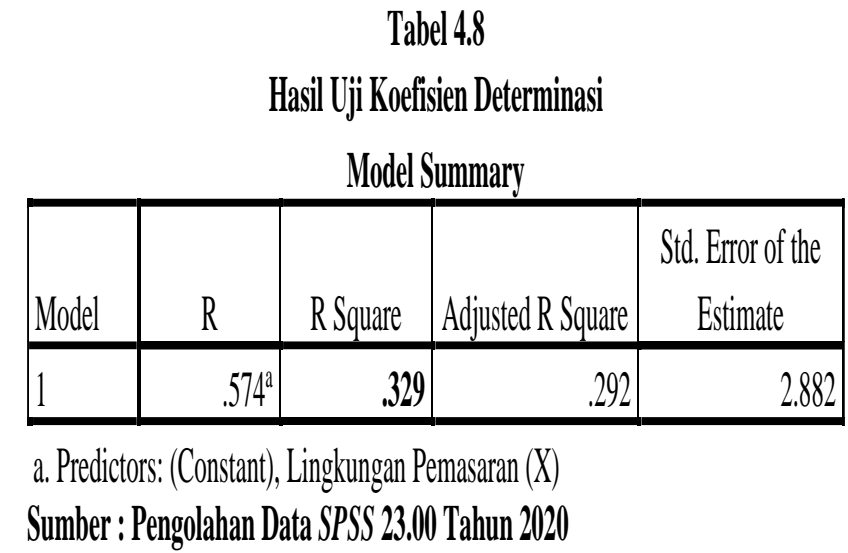

Pengujian koefisien determinasi $\left(\mathrm{r}^{2}\right)$ digunakan untuk mengukur proporsi atau persentase kemampuan model dalam menerangkan variabel terikat. Koefisien determinasi berkisar antara nol sampai satu $(0$ $\leq \mathrm{R}^{2} \geq 1$ ). Jika $\mathrm{R}^{2}$ semakin besar (mendekati satu), maka dapat dikatakan bahwa pengaruh variabel bebas (X) adalah besar terhadap variabel terikat $(\mathrm{Y})$.

Hal ini berarti model yang digunakan semakin kuat untuk menerangkan pengaruh variabel bebas terhadap variabel terikat dan demikian sebaliknya.Berdasarkan Tabel Coeffisien $^{a}$ nilai Koefisien Determinasi sebesar 0,329. Dapat kita lihat seperti dibawah ini:

$$
\begin{aligned}
& \mathrm{KD}=\mathbf{r}^{2} \times 100 \% \\
& \mathrm{KD}=\mathbf{0 , 3 2 9} \times 100 \% \\
& \mathrm{KD}=\mathbf{3 2 , 9} \%
\end{aligned}
$$

Seperti perhitungandiatasbahwa variabel Lingkungan Pemasaran (X) mampu menjelaskan sebanyak $32,9 \%$ perubahan dari Pendapatan (Y) pada Usaha Sentra Industri 
Pemgolahan Salak Agrina Parsalakan. Sedangkan sisanya sebesar $67,1 \%$ dijelaskan oleh faktor lain yang tidak diteliti oleh peneliti.

\section{PEMBAHASAN}

Dari pengujian variabel penelitian secara parsial, didapati bahwa variabel independen yaitu Lingkungan Pemasaran (X) positif dan signifikan terhadap Pendapatan (Y) Pada Usaha Sentra Industri Pengolahan Salak Agrina Parsalakan. Nilai signifikan ini untuk variabel Lingkungan Pemasaran (X) dengan nilai $t_{\text {hitung }}>t_{\text {tabel }}(2,973>1,734)$.Hal ini terlihat dari distribusi tanggapan responden dengan frekuensi dan persentase terbesar untuk variabel Lingkungan Pemasaran (X) yang mayoritas tanggapan responden "Setuju" bahwa Lingkungan Pemasaran tersebut berpengaruh terhadap Kepuasan Pelanggan Usaha Sentra Industri Pengolahan Salak Agrina Parsalakan. Dikatakan berpengaruh positif dan signifikan sebab nilai thitung $>t_{\text {tabel. }}$. Penelitian ini menemukan hasil dari nilai Koefisien Determinasi pada tabel Coefficients ${ }^{a}$ sebesar 0,329 (dapat dilihat pada tabel Coeffisien ${ }^{a}$ di lampiran table 4.8), yang menunjukkan bahwa variabel Lingkungan Pemasaran (X) mampu menjelaskan sebanyak 32,9\% perubahan dari Pendapatan (Y) Usaha Sentra Industri Pengolan Salak Agrina Parsalakan. Sedangkan sisanya sebesar $67,1 \%$ dijelaskan oleh faktor lain yang tidak diteliti oleh peneliti.Dengan demikian dapat disimpulkan bahwa variabel Lingkungan Pemasaran (X) dengan tingkat signifikan0.590menunjukkan secara serempak berpengaruh secara positif dan signifikan terhadap Pendapatan pada Usaha Sentra Industri Pengolahan Salak Agrina Parsalakan.

\section{KESIMPULAN}

\section{Kesimpulan}

1. Berdasarkan perhitungan yang diperoleh dengan uji validitas bahwa instrument dalam penilitian ini dianggap valid begitu juga dengan uji reabilitas dalam penelitian ini adalah reliable.

2. Konstanta sebesar 8,501, artinya jika Lingkungan Pemasaran (X) nilainya adalah 0, maka jumlah Pendapatan (Y) nilainya positif yaitu sebesar 0,590.Ini berarti bahwa variable Lingkungan Pemasaran (X) berpengaruh positif terhadap Pendapatan (Y) Pada Usaha Sentra Industri Pengolahan Salak Agrina Parsalakan

3. Berdasarkan pengujian variabel Lingkungan Pemasaran penelitian secara parsial, didapati bahwa variabel independen yaitu secara positif dan signifikan berpengaruh terhadap variabel dependen yaitu Pendapatan di Usaha 
Sentra Industri Pengolahan Salak Agrina Parsalakan Nilai signifikan ini untuk variabel Lingkungan Pemasaran (X) dengan nilaithitung $>t_{\text {table }}(2,973>1,734)$.

4. Berdasarkan pengaruh Lingkungan Pemasaran terhadap Pendapatan, dapat diperoleh kesimpulanya itu hasil analisis data menunjukkan sebanyak 32,9\% perubahandari Pendapatan (Y) pada Usaha Sentra Industri Pengolaan Salak Agrina Pesalakan Sedangkan sisanya sebesar $67,1 \%$ dijelaskan oleh faktor lain yang tidak diteliti oleh peneliti.

\section{DAFTAR PUSTAKA}

Arikunto Suharsimi. 2006. Metode Penelitian. Jakarta : UPI.

Fandy Tjiptono. 2008. Strategi Pemasaran Edisi ke-3 .Yogyakarta :Andi.

Fuad, Christin, Nurlela, Sugianto, Paulus. 2009. Pengantar Bisnis. Jakarta : Gramedia Pustaka Utama.

Greuning, et al. 2013. International Financial

Reporting Standars, Edisi ke 6. Jakarta:

Salemba Empat.

Hans Kartikahadi. 2012. Akuntansi Keuangan

Berdasarkan SAK berbasi IFRS. Jakarta:

Salemba.

Ikatan Akuntansi Indonesia. 2015. Pernyataan Standart Akuntansi Keuangan

Kotler dan Keller.2007, Manajemen Pemasaran Jilid I, Edisi Kedua belas.
Jakarta :Indeks. 2008. Prinsip-Prinsip

PemasaranJilid 1. Jakarta :Erlangga.

Kotler dan Keller.2009. Manajemen

Pemasaran Jilid I. Edisike 13. Jakarta: Erlangga.

Lau, Peter dan Nelson, Lam. 2014. Akuntansi

Keuangan ( Internmediate Financial

Reporting) Buku 1. Jakarta : Salambe Empat.

Martani, Dwi.dkk (2016). Akuntansi

Keuangan Menengah Berbasis PSAK (ed.

2, buku 1). Jakarta: Salemba Empat.

M. Nasution. 2005. Total Quality Management. Jakarta :Gramedia Pustaka Utama.

Morgan, R.M and Hunt,S.D. 2005. The Commitment-Trust Theory Of Relationship Marketing .JurnalOf Marketing, Vol.58, No.3, PP.20-38.

Ndubisi, Nelson O. 2007. Relationship Marketing And Customer Loyalty. Marketing Inteligence And Planning. Vol. 25.No.1. PG98-106.

Philip \& Duncan. 2012. Marketing Principles and Methods. Georgetown : Richard D. Irwin. Inc.

Ranu pandojo dan Husni. 2006. Manajemen Dasar. Jakarta :Bumi Aksara.

Sulistiono. 2010. Pengaruh Kepemilikan Manajerial, Struktur Modal dan Ukuran Perusahaan terhadap Nilai Perusahaan pada Perusahaan Manufaktur di BEI 
Tahun 2006-2008. Skripsi. Semarang: Universitas Negeri Semarang.

Stanton William. 2012. Dasar-dasar Manajemen Pemasaran. Yogyakarta : Danang Sunyoto

Sivesan. 2012. Impact Of Relationship Marketing On Costumer Loyalty On Banking Sectors. Jurnals OF South Academic Research. Volume 2, Issue 3, PP.179-191.

Sugiyono, 2012.Metode Penelitian Bisnis. Alfabeta : Bandung. Sugiyono. 2013. Metode Penelitian Bisnis. Bandung : CV. Alfabeta. 